\title{
Impact of Gender Difference on Crop Productivity: Cross-sectional Data
}

\author{
GETINET GEZAHEGN GEBRE \\ Lecturer, Department of Economics, Bonga University, Ethiopia
}

\begin{abstract}
The study examined impact of gender difference on Crop productivity in Decha woreda of south west Kafa zone, located at $23 \mathrm{Km}$ from Bonga Town, and $473 \mathrm{~km}$ south west of Addis Ababa. The specific objectives were to assess the extent to which the agricultural production system is gender oriented; to examine access and control over productive resources; and to examine which households are disadvantageous in control over productive resources. Cross-sectional data collected from a total of 140 respondents were used in this study whereby 65 were female headed and 75 were male headed households. The data were analyzed by using Statistical Package for Social Science (SPSS). Descriptive statistics such as frequency, mean, percentage, pie chart, bar graph, t-test and chi-square were used to summarize and compare the information between the two groups. Moreover, CobbDouglas (CD) production function was used to estimate the productivity difference in agriculture between male and female headed households. Results of the study showed that male headed households (MHH) own more of productive resources such as land, livestock, labor and other agricultural inputs as compared to female headed households (FHH). Moreover, the estimate of CD production function shows that livestock, herbicide use, land size and male labor were statistically significant for $\mathrm{MHH}$ while livestock, land size, herbicides use and female labor were significant variables for FHH. However, if FHH had equal access to the inputs as MHH, gross value of the output would be higher by $23.58 \%$ for FHH. This may suggest that FHH would be more productive than $\mathrm{MHH}$ if they had equal access to inputs as MHH. Additionally, accessing of FHH inputs that increase the productivity of agriculture such as herbicides, livestock and male labor; increasing the productivity of land; and introducing technologies that reduce the time and energy of women especially for enset processing.
\end{abstract}

Keywords: Gender, Crop, Productivity, Efficiency

DOI: $10.7176 / \mathrm{JESD} / 11-1-02$

Publication date: January $31^{\text {st }} 2020$

\section{INTRODUCTION}

Agriculture is the major economic sector and the main source of livelihood for the majority of the people in Ethiopia. According to CSA (2011), 85 percent of the total population of the nation lives in rural areas and 90 percent of the population depends on the agricultural sector.

Additionally, the agricultural sector contributes 50 percent to the GDP, 70 percent to the export earnings and employee's 80 percent of the workforce. Hence, the overall performance of the Ethiopian economy is highly influenced by the performance of the agricultural sector. All in all, economic development in this nation cannot be envisaged without the development of agriculture and hence poverty reduction is closely related to the development of this sector (MoFED, 2015).

"Women are the back bone of farming in Africa, just as they are in most of the world. And, so we want a good collaboration to make sure that women are the same partners with men farmers all the way through the process... to enable... farmers who are women to contribute that will transform agriculture, add to the gross domestic product of their nations, give them more income to educate their children to have a better life" (Clinton, 2009).

Agriculture in the study area is characterized by rain-fed and subsistence nature which serve as main source livelihood. Overcoming agricultural stagnation and food insecurity mainly depends on increasing agricultural productivity. In Ethiopia, like in many other parts of sub-Saharan Africa, where subsistence agriculture predominates, placing strong emphasis on increasing the productivity of labor, land, capital and other resources has paramount importance.

Agricultural productivity in Ethiopia is disadvantaged by many factors among which land degradation, less access to land, and government services including credit, educational opportunities are the major factors, which are aggress the overall sustainability of agricultural production of the country (CSA, 2012).

Female headed households have less access to land, labor, well-paying jobs and government services including credit, educational opportunities (Ellen, 2013; World Bank, 2014b). In most African nation's female headed households are the first to suffer through when economic, political and environmental deterioration occur and the final to gain when there are improvements (Elabour, 2011).

Moreover, the proportion of women and their children who live in poverty has been rising. Reasons for the increase are multifaceted, including the breakup of the traditional family system and the increase of single headed households; the sex specific migration resulting in left behind female heads in place of beginning and the 
transformation of the global economy, which has shifted patterns of employment (Lisa and Ritu,2005; Buvinic and Gupta, 2012).

Female headed households have restricted access to and control over resources, which is crucial to effectively and efficiently meeting their strategic and practical needs due to social and cultural biases in the society (Tiruwork, 2010; Addis, 2010; Dejene, 2014). There are differences in terms of access to and control over resources and decision-making between these females headed households.

Generally, women's contributions in rural Ethiopia have remained invisible; especially, female headed households are more invisible to researchers, donors and policy makers (Addis, 2010; Tiruwork, 2010). These situations have put women at disadvantageous position with respect to agricultural resources, leading to low productivity of female headed households. Thus, there is no uniformity among scholars and researchers on the impact of gender difference on crop productivity.

As agriculture is the core of the country's economy, it can contribute much to the development through the improvement of the productivity of the sector in the past was very low due to different reasons. Understanding the difference between households help to design means of developing the agricultural sector and thus essential for the long-term success of the economy. On the other hand, the causes of gender related differences in productivity is essential, because, if gender affects the productivity directly, meaning, if men's and women's productivities are different when they have exactly the similar constraints and resources, then it may be necessary to modify research strategies to ensure rising their productivity. Therefore, the end result of this study enables us to know the sources of crop productivity difference between men and women farmers working in a similar environment.

The study, furthermore, provides some basic information needed by policy makers and institutions interested in designing programs and projects that are appropriate to the needs of both men and women.

Regarding geographical scope, the study was conducted household level analysis based on crop productivity data that was obtained by household level. The subject matter of the scope is limited to the impact of Gender difference on crop aspect.

This paper is organized as follows: section 2 provides literature reviews, including theoretical and empirical evidence on Impact of Gender difference on crop productivity. Section 3 discusses Model specification, data source and description, estimation techniques. Section 4 presents analysis and results of the study. Finally, section 5 presents conclusion and policy implication based on the estimated results.

\section{RELATED LITERATURE REVIEW}

\section{Theoretical Literature}

Under this part an attempt is made to discuss some of the concepts used in this study such as gender and its role, gender gap, household headship, role of gender in agriculture and measurement of productivity in agriculture.

Gender is one of the ways in which societies and smaller social groups are stratified. In other word, gender is an established social and cultural role of men and women or it is a system of roles and relationships between men and women that are determined by the social, political and economic concepts (Laura, 2011).

Roles differ in different settings and culture of a society. It is also interdependent, learned, dynamic (changes over time) and multi-faceted (differ within and between cultures). Since gender is created by society, its meaning varies from society to society and changes overtime (John and David, 2011). Many authors argue that cultural ideology about men's and women's roles is a critical factor in determining the way gender relationships on crop production are ordered in a given society and, therefore, must be seriously considered in development planning (Tiruwork, 2010).

In all societies, men and women play dissimilar roles, have different needs and face different constraints. Gender roles are dissimilar from the biological roles of men and women, although they may overlap in practically all societies. Women's biological role in child bearing may extend their gender roles to child rearing, food preparation and household maintenance. Among some groups, for instance, women are responsible for milking; in others, men do this work and etc.

Gender roles differentiate responsibilities between men and women in social and economic activities, access to resources and decision-making authority. Biological roles are fixed but gender roles can and do shift with socioeconomic and technological changes. For example, the introduction of new crops and technologies, mounting pressure on land, or rising poverty or migration can change the roles of men and women in agriculture (World Bank, 2015).

There are socio-economic indicators of gender inequality. These include measure of employment, education, health, ownership of property and income disparities. Gender gap results from inequality in decision making power which leads to inequality in access to resources and by the differential treatment given to women and girls as compared to that given to men and boys.

\section{Measurement of Productivity in Agriculture}

In theory of economics, productivity is defined in terms of the rate of output produced per unit of input utilized, if 
the production process involves a single input and output. Beyond the single output and single input case, however, the definition and measurement of productivity become less straight forward (Antle and Capalbo, 2008; Coelli, 2015).

The birth of modern theory of productivity took place in 1957, when Robert Solow started the profession by the findings of his research, which won him noble prize (Solow, 1957). Productivity is the major component of growth. The importance of productivity in economic development is universally recognized. The economic achievement of some of the developed countries is attributed to increase in productivity. Changes in productivity become more important for countries where the resources are limited in supply and have very high social opportunity cost.

The relationship between inputs and outputs in a production process of a firm or any production unit can be investigated through the application of a production function. According to Heady and Dillon (2011), a production function is a technical relationship between output and factors of production (such as labor, land capital and other inputs) of any production unit. In other words, a production function shows the maximum output that can be produced from given quantities of input with a given state of technology. The production function, therefore, represents the technology used by the farmers based on the technical methods of production. Such inputs and output relationship in a production function is often represented by the following Function $\mathrm{Y}=\mathrm{f}\left(\mathrm{X}_{1}, \mathrm{X}_{2} \ldots \mathrm{X}_{\mathrm{n}}, \mathrm{U}\right)$

Where, $\mathrm{Y}$ denotes the output, $\mathrm{Xi}$ is the amount of input factors, $\mathrm{f}$ is the functional form relating to the output and the ' $n$ ' variable inputs and $U$ is disturbance term. The female farmers' production function may be below the male production function because they may use traditional technologies, due to lack of knowledge, lack of access to modern inputs, or higher costs to adopting the new technologies.

$\mathrm{CD}$ production function is one of the most widely used functions in the economic analysis of problems related to empirical productivity estimation in agriculture and industry.

The CD production function has the following features where some of them make it so interesting and popular. First, the function is homogenous. The sum of the parameters has interesting economic interpretation since it gives information about the returns to scale or the scale of operation of the production process. The returns to scale are increasing, constant or decreasing depending on whether the sum is greater than one $(a+b>1)$, equal to one (a+ $b=1)$ or less than one $(a+b<1)$, respectively. Secondly, the function is strictly quasi concave for positive values of inputs; and its isoquants are negatively slopped throughout and strictly concave for positive value of inputs. Thirdly, the function yields diminishing return to each input, i.e. the value of the production elasticities are less than one.

\section{Review of Empirical Findings}

Various studies within the country or across countries may find different results on the impact of gender difference on crop production. Some studies argue that gender has significant role in crop productivity while other argues that gender has no role in crop productivity. Structural or institutional factors may contribute to gender differences in productivity as agricultural systems are modernized. According to Boserup (2009) made the classic feminist argument linking resources to productivity. She concluded that the tendency towards a widening productivity gap is often exacerbated by cash crop cultivation among men, while women produce food crops for the family without cash income for investment in farming technique.

\section{DATA AND METHODOLOGY}

\section{Source and Type of Data}

Both primary and secondary data collected were used. Primary data were collected from sample households through structured questionnaire, interview and secondary data from concerned line offices such as agricultural office, education office, and from administration office of the woreda. Reviews of relevant books, journals, articles, and other published and unpublished document was also carried out.

A Multiple stage random sampling technique was used to select the sample households in the study area. The first stage was simple random sampling of 6 PAs from the 23 PAs found in the district. Then from 6 PAs a total of 75 male headed and 65 female headed households were randomly selected. Hence, a total of 140 households were interviewed.

Therefore, the sample size determination formula adopted for this study is: (According to Yeman, (1967), sampling technique)

$\mathrm{n}=\mathrm{N}$
$1+\mathrm{Ne}^{2}$

Where:

$\mathrm{n}=$ sample size of the population of (140),

$\mathrm{N}=$ total population (216) and

$\mathrm{e}^{\mathrm{i}}=$ margin of error $(5 \%), 0.05$ 
Table 2. Distribution of Sample Households by PA and Sex of Household Head

\begin{tabular}{|c|c|c|c|c|c|}
\hline \multicolumn{2}{|l|}{ Name of PA } & \multicolumn{2}{|l|}{ HHs } & \multicolumn{2}{|c|}{ Sample } \\
\hline & $\mathrm{MHH}$ & $\mathrm{FHH}$ & $\mathrm{MHH}$ & $\mathrm{FHH}$ & Total \\
\hline Decha Association & 20 & 15 & 13 & 10 & 23 \\
\hline Millinium & 18 & 16 & 12 & 10 & 22 \\
\hline Dubiyo & 23 & 18 & 16 & 12 & 28 \\
\hline Abiren Enideg & 17 & 15 & 10 & 10 & 20 \\
\hline Decha lijochi & 17 & 19 & 10 & 12 & 22 \\
\hline Noonnaa Noona & 21 & 17 & 14 & 11 & 25 \\
\hline Total & 116 & 100 & 75 & 65 & 140 \\
\hline
\end{tabular}

Source: Decha woreda agricultural office analysis (2018/19) and Own Sampling.

Both descriptive and econometric analyses were employed to meet the specific objectives of the study. In descriptive statistics such as mean, frequency, percentage, t-test, and chi-square were used to analyze the collected data.

\section{Model Specification}

\section{Cobb-Douglas Production Function}

CD production function was used to examine the agricultural productivity differences between the female and male headed households. It refers to the production function in which one input can be substituted by other but to a limited extent. These are making it possible to change the algebraic form in log linear form, this production function has been estimated with the help of linear regression analysis.

According to Gujarat (1995), the generalized form of the CD production function can be specified as: $\mathrm{Yi}=\mathrm{aX}_{1}{ }^{\mathrm{b} 1} \mathrm{X}_{2}^{\mathrm{b} 2} \mathrm{X}_{3}^{\mathrm{b} 3} \ldots \mathrm{X}_{\mathrm{n}}^{\mathrm{bn}} \mathrm{e}^{\mathrm{ui}}$ .2

Where: Yi is Dependent Variable that is gross value of farm outputs, Xn's are explanatory variables such as land size, livestock holding, education level fertilizer use, herbicides use, male and female labor; bn's are coefficients of output; $a$ is efficiency parameter and Ui is disturbance term.

Since the CD production function is a power function, it is impossible to directly use the Ordinary Least Square (OLS) Method. Therefore, logarithmic transformation was made to obtain its linear form and to estimate the parameters. In this study, the natural logarithm was employed.

To examine whether the production functions of male headed (MHH) and female headed households (FHH) are different from each other, Equation (2) was estimated separately for MHH and FHH. In the context of multiple regressions, there is no need to stop with seven independent variables. The regression analysis allows many observed factors to affect $\mathrm{y}$. The respective transformed models are shown as follows:

Productions function for $\mathrm{MHH}$ :

$\mathrm{LnYm}=\ln \mathrm{A}_{\mathrm{m}}+\mathrm{B}_{1 \mathrm{~m}} \ln \mathrm{X}_{1 \mathrm{~m}}+\mathrm{B}_{2 \mathrm{~m}} \ln \mathrm{X}_{2 \mathrm{~m}}+\mathrm{B}_{3 \mathrm{~m}} \ln \mathrm{X}_{3 \mathrm{~m}}+\mathrm{B}_{4 \mathrm{~m}} \ln \mathrm{X}_{4 \mathrm{~m}}+\mathrm{B}_{5 \mathrm{~m}} \ln \mathrm{X}_{5 \mathrm{~m}}+\mathrm{B}_{6 \mathrm{~m}} \ln \mathrm{X}_{6 \mathrm{~m}}+\mathrm{B}_{7 \mathrm{~m}} \ln \mathrm{X}_{7 \mathrm{~m}}+\mathrm{e}_{\mathrm{m}}$

Productions function for $\mathrm{FHH}$ :

$\mathrm{LnYf}=\ln \mathrm{A}_{\mathrm{f}}+\mathrm{B}_{1 \mathrm{f}} \ln \mathrm{X}_{1 \mathrm{f}}+\mathrm{B}_{2 \mathrm{f}} \ln \mathrm{X}_{2 \mathrm{f}}+\mathrm{B}_{3 \mathrm{f}} \ln \mathrm{X}_{3 \mathrm{f}}+\mathrm{B}_{4 \mathrm{f}} \ln \mathrm{X}_{4 \mathrm{f}}+\mathrm{B}_{5 \mathrm{f}} \ln \mathrm{X}_{5 \mathrm{f}}+\mathrm{B}_{6 \mathrm{f}} \ln \mathrm{X}_{6 \mathrm{f}}+\mathrm{B}_{7 \mathrm{f}} \ln \mathrm{X}_{7 \mathrm{f}}+\mathrm{ei}$

Where, there are $\mathrm{X}$ independent variables and an intercept contains $\mathrm{X}+1$ (unknown) population parameters. For short hand purposes, we will sometimes refer to the parameters other than the intercept as slope parameters, $\mathrm{Ai}=$ intercept, $\mathrm{Bi}=$ Coefficients, $\mathrm{e}=$ Error term, $\mathrm{Xi}=$ Explanatory variables.

The estimation technique employed in this study was OLS. The OLS has very attractive statistical properties that have made it one of the most powerful and popular methods of regression analysis including linearity, and minimum variance (Koutsoyiannis, 2007). All the production functions were estimated separately using OLS techniques with the help of Statistical Package for Social Science (SPSS) computer software. 
Table: The main summary of categorical variables in the model and their an expected sign

\begin{tabular}{|c|c|c|c|c|}
\hline No & Coefficient & $\begin{array}{l}\text { the represented } \\
\text { Variable name }\end{array}$ & $\begin{array}{r}\text { Expected } \\
\text { signs }\end{array}$ & $\begin{array}{l}\text { Reasons for an } \\
\text { expected signs }\end{array}$ \\
\hline 1 & Crpro & $\begin{array}{l}\text { Crop productivity } \\
\text { (Crpro) }\end{array}$ & - & - \\
\hline 2 & $\beta 0$ & Constant & - & - \\
\hline 3 & $\beta 1$ & $\begin{array}{l}\text { Livestock } \\
\text { size (Silst) }\end{array}$ & $+\mathrm{ve}$ & $\begin{array}{l}\text { have opportunity to acquire production } \\
\text { inputs \& improve his/her productivity }\end{array}$ \\
\hline 4 & $\boldsymbol{\beta} 2$ & $\begin{array}{l}\text { Land size } \\
\text { (lnsiz) }\end{array}$ & + ve & $\begin{array}{l}\text { expected to have higher gross value of } \\
\text { farm output }\end{array}$ \\
\hline 5 & $\beta 3$ & $\begin{array}{l}\text { Education } \\
\text { (eduhh) }\end{array}$ & $+\mathrm{ve}$ & $\begin{array}{l}\text { Have a bearing on farmers access to } \\
\text { improved farm techniques and effective } \\
\text { use of information available on } \\
\text { technologies }\end{array}$ \\
\hline 6 & $\boldsymbol{\beta} 4$ & $\begin{array}{l}\text { Inorganic } \\
\text { fertilizer(infert) }\end{array}$ & $+\mathrm{ve}$ & used to increase soil fertility \\
\hline 7 & $\beta 5$ & $\begin{array}{l}\text { Herbicides } \\
\text { (herc) }\end{array}$ & $+\mathrm{ve}$ & used in liter per ha to control weeds \\
\hline 8 & $\beta 6$ & Experience & + ve & An increase productivity \\
\hline 9 & $\beta 6$ & $\begin{array}{l}\text { Labour } \\
\text { (labmf) }\end{array}$ & $+\mathrm{ve}$ & $\begin{array}{l}\text { An increase in man/women-days } \\
\text { increases the productivity }\end{array}$ \\
\hline 10 & $\boldsymbol{\beta} 7$ & Error term & & \\
\hline
\end{tabular}

\section{RESULT AND DISCUSSION}

The result of level of education is consistent with Haymanot, (2014) in affecting male and female involvement in major decision-making process. The educational status indicates that about $13 \%$ of the FHH were illiterate; about $22 \%$ of the FHH were attended literacy (1-5 Grades), around 11\% had Grade 6-10 and no greater than Grade 10 had FHH. In contrast, about $17 \%$ of $\mathrm{MHH}$ were illiterate, about $24 \%$ of the Male were attended literacy, about $12 \%$ of the MHH had Grade 6-10, about $1 \%$ of the $\mathrm{MHH}$ were greater than Grade 10 student.

On the mean of male households head attended 2.73 years of schooling while that of female heads attended 0.75 years. This shows that there is a significant difference $(\mathrm{t}=4.56)$ in terms of access to formal education between $\mathrm{MHH}$ and $\mathrm{FHH}$.

This also indicates that children in FHH had less access to education as compared to that of children in MHH. In general, FHH had less access to formal education as compared to MHH in the study area. The literacy rate in the selected kebeles, according to data from the education office of the district, is about $31.4 \%$.

Table Frequency of educational status of Household Head

\begin{tabular}{llcccccc}
\hline \hline Educational group & \multicolumn{3}{c}{ frequency } & \multicolumn{3}{c}{ (Percentage) $\%$} \\
\hline \hline & Male & Female & Total & Male & Female & Total \\
\hline \hline Illiterates & 24 & 18 & 42 & 17 & 13 & 30 \\
$1-5$ & 33 & 32 & 65 & 24 & 22 & 46 \\
$6-10$ & 17 & 15 & 32 & 12 & 11 & 23 \\
$>10$ & 1 & - & 1 & 1 & - & 1 \\
Total sample & 75 & 65 & 140 & 54 & 46 & 100 \\
$\quad$ Total & & 140 & & \multicolumn{2}{c}{100} \\
\hline \hline
\end{tabular}

Source: Source Group Household Head (AE) 2019 data from own survey

According to the information from the woreda council, some of them migrate to other places like Jimma (coffee picking), Bonga (trade), Addis Ababa (searching of job), Dima (Gold extraction), etc. The number of migrant's peoples from the woreda is relatively higher in town.

\section{Land Use Pattern}

The total area of land owned by the sample farmers was about 12,626 ha with the average of 0.91 ha per household. Compared to the woreda average, which was 1.13 ha, land holding under different uses was small in the study area. The land use pattern of household under uncultivated is $18 \%$. MHH $10 \%$ and FHH $8 \%$ was statistically different at $1 \%$ probability level $(\mathrm{t}=3.35)$. This indicates that landholdings of the households headed by women are smaller by $46 \%$ than that of the male headed. According to the information obtained from the woreda council he/she doesn't agreement between families, scarcity of land is the major cause for migration of males to other areas.

Background of livestock is another economic activity in which, about $64.5 \%$ of the total sampled households 
are in the sector. Out of these, MHH $44.3 \%$ and FHH 20.2\% participate along with crop production. The remaining 35.7 of MHH $20 \%$ and FHH $15.7 \%$ reported to have no livestock.

Table10: Frequency of Livestock Ownership

\begin{tabular}{lcccccc}
\hline Type & \multicolumn{5}{c}{ Frequency } & \multicolumn{3}{c}{ Percentage (\%) } \\
Livestock & Male & Female & Total & Male & Female & Total \\
No Livestock & 50 & 40 & 90 & 36 & 28 & 64 \\
Total & 25 & 25 & 50 & 18 & 18 & 36 \\
& 75 & 65 & 140 & 54 & 46 & 100 \\
\hline
\end{tabular}

Source: own survey, 2019

Labor is an important factor in determining the output. Agricultural labor among the community can be divided into three: first, family labor, which consists of the labor force of all able persons residing within the household. The second is hired labor, which simply engages in the agricultural fieldwork of the household and paid at the end of the working day (Daado). The third form of agricultural labor that a household organizes is debo. A household can organize work party such as debo when it finds that particular agricultural task cannot be managed by the household labor alone.

With regard to herbicides $74 \%$, about $48 \%$ of $\mathrm{MHH}$ and $26 \%$ of FHH used herbicides to control weeds. The mean amount used by MHH and FHH was about 0.26 and 0.19 liter respectively. This amount is below the recommended rate of one liter per hectare, according to the information from the agricultural office of the district. The respondents pointed out that "geeco" (Chiogogiti), and "Tuffo" are the major weed species in the area. Figure: Frequency of the Use of Fertilizer, Herbicides and Improved Seed:

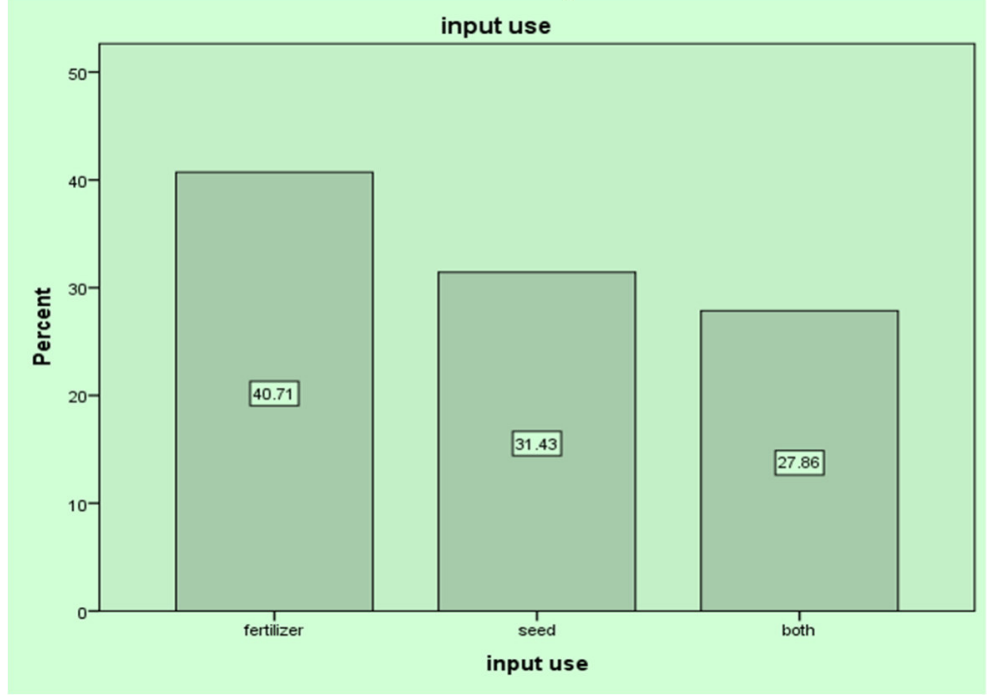

Source: own computation, 2019

The result of level of major crop is consistent with Haymanot, (2014) in affecting male and female on productivity. The average yield of coffee for MHH 30\% and FHH $22 \%$ was about $52 \%$, which was statistically significant at $5 \%(\mathrm{t}=1.75)$. The average yields of, barely, wheat and maize was about $10 \%$, and for the respective yield of Enset were 35\%.

Table: Frequency yield of Major Crops

\begin{tabular}{lcccccc}
\hline \hline Type & \multicolumn{3}{c}{ Frequency } & \multicolumn{4}{c}{ Percentage $(\%)$} \\
\hline \hline & Male & Female & Total & Male & Female & Total \\
\hline \hline Coffee & 40 & 37 & 77 & 29 & 26 & 55 \\
Enset & 25 & 24 & 49 & 18 & 17 & 35 \\
Barely & 10 & 4 & 14 & 7 & 3 & 10 \\
Total & 75 & 65 & 140 & 54 & 46 & 100 \\
\hline \hline
\end{tabular}

Source: Own computation, 2019

Land preparation is carried out using oxen as draught animal and, especially those in dega agro-climatic zone. Ploughing is entirely men's activity.

Other agricultural activities are shared with women. Digging and weeding is a responsibility of both men and women and is done either alone or together. But not all crops need both digging and weeding. Digging is mainly for maize followed by weeding. In most cases weeding is one time activity. Weeding is unavoidable for maize and is a usual task for teff. 
After that weeding, digging, harvesting, collecting and threshing in order are relatively common tasks of women in the area. Preparing the threshing ground is a woman's task while threshing is done by men (majority) and women (few especially in FHH where there is no male). Collecting and transporting is frequently done by women but using pack animals men do transport grain from field to home.

Food preparations including grinding of grains, preparing coffee, etc are mainly done by women. They are also responsible for cleaning the house, fuel collection (either cow dung or fire wood) and water fetching. Tending of children is mainly the duty of women, too.

The distinction between access and control is based on the conceptual separation of the use of resources and services and the benefits derived from their use. According to CISP (2007), access can be defined as "the opportunity to make use of something" and control as "the ability to decide the use of something". The distinction is important because access does not necessarily imply that an individual controls a particular resource or the benefits from its utilization. For instance, a woman may earn an income from productive activities but have no control over how it is spent. Generally, access is a pre-condition for control. Below are brief discussions on access and control over major productive resources, both physical and institutional, by male and female households.

The land used for cultivation can also be obtained through land transaction. Accordingly, about $57.5 \%$ of $\mathrm{MHH} 46.5 \%$ and $\mathrm{FHH} 11 \%$ have own land. Inversely, about $39.3 \%$ of FHH $11 \%$ and $28.5 \%$ of MHH have no owned land. The others access land through renting MHH $29 \%$ and FHH $19 \%$ and borrowing of MHH and FHH, 1 and 5 , respectively.

Moreover, about $11 \%$ of FHH have no access to land at all while all of the samples MHH have access to land either from rented, borrowed or shared.

Table 16: Type of Land Access by Gender

\begin{tabular}{|c|c|c|c|c|c|}
\hline \multirow[t]{2}{*}{ Access } & \multicolumn{2}{|c|}{ MHH $(\mathrm{N}=75)$} & \multirow{2}{*}{$\begin{array}{r}\text { FHH }(\mathrm{N}=65) \\
\% \text { of } \mathrm{HH}\end{array}$} & \multirow[b]{2}{*}{ Mean (ha) } & \multirow{2}{*}{$\begin{array}{l}\text { t-value } \\
\text { (Mean) }\end{array}$} \\
\hline & $\%$ of $\mathrm{HH}$ & Mean (ha) & & & \\
\hline Owned & $\overline{446.5}$ & 1.06 & 11 & 0.72 & 3.35 \\
\hline Rented & 29 & 0.17 & 19 & 0.10 & 1.53 \\
\hline Borrowed & 1 & 0.002 & 5 & 0.009 & -1.42 \\
\hline Shared & 8 & 0.03 & 20 & 0.13 & -2.27 \\
\hline No access & 28.5 & 0.16 & 11 & 0.72 & 3.35 \\
\hline
\end{tabular}

Source: Own Computation, 2019; NB: Significant at 5\% probability level.

As discussed, the results of this study are consistent with the studies stated above. In general, differential access to and control of resources between the two sexes in the area seems to be a direct reflection of the culturally prescribed gender division of labor. For instance, as long as milking cows is an exclusive activity of women, they continue to enjoy full rights to dispose of butter and milk. Likewise, men do plough using oxen for production of crops over which they have complete control.

Table: Access and Control Profile of Resources and Benefits

\begin{tabular}{lcccc}
\hline \hline \multicolumn{2}{c}{ MHH } & \multicolumn{4}{c}{ FHH } \\
\hline \hline Item & Access & Control & Access & Control \\
\hline \hline Land & $\mathrm{x}$ & $\mathrm{x}$ & $\mathrm{x}$ & $\mathrm{x}$ \\
Farm tools & $\mathrm{x}$ & $\mathrm{x}$ & $\mathrm{x}$ & $\mathrm{x}$ \\
Farm oxen & $\mathrm{x}$ & $\mathrm{x}$ & $\mathrm{x}$ & - \\
Farm inputs & $\mathrm{x}$ & $\mathrm{x}$ & $\mathrm{x}$ & $\mathrm{x}$ \\
Cow & $\mathrm{x}$ & $\mathrm{x}$ & $\mathrm{x}$ & $\mathrm{x}$ \\
Sheep/goat & $\mathrm{x}$ & $\mathrm{x}$ & $\mathrm{x}$ & $\mathrm{x}$ \\
Pack animal & $\mathrm{x}$ & $\mathrm{x}$ & $\mathrm{x}$ & - \\
Chicken & $\mathrm{x}$ & $\mathrm{x}$ & $\mathrm{x}$ & $\mathrm{x}$ \\
Livestock products & $\mathrm{x}$ & - & $\mathrm{x}$ \\
\hline \hline
\end{tabular}

Source: Own computation, $2019 \mathrm{x}=$ access and control, $(-)=$ no access and control

Women and men in the study area have no equal share regarding decision-making power in the household and even at the community level. In some cases, the decision-making power is closely associated with the pattern of the gender division of labor. 
Table: Proportion of Households Participating in Decision Making (\%)

\begin{tabular}{lcc}
\hline Activities & MHH ( N=75) \% & FHH(N=65)\% \\
\hline Sale of livestock & 38.8 & 70 \\
Sale of cash crop & 80.0 & 50 \\
Sale of food crops & 22.5 & 71.7 \\
Use of income & 37.3 & 73.4 \\
Use of agricultural input & 64.2 & 70.4 \\
Use of fixed assets & 31.9 & 72.7 \\
Cropping calendar & 67.6 & 63.3 \\
\hline \hline
\end{tabular}

Source: Own survey (2019) NB: Significant at 5\% probability level

In the area of the study, men dominate the decision to buy or sell animals such as cow, oxen, horses, donkey and sheep. Nevertheless, most women said that they are consulted before such a decision is taken. Sales of livestock products such as eggs and milk are decided by women.

They utilize the income obtained for buying food items such as salt, oil, coffee, etc. Their proverb goes in line with this "Gaatona bi gochibeetonon yechibeeto anamo", "minji enjoonaa boonosh wane daanebeetonon yechibeeto Geeno", meaning ox and its products belong to men, as cow and its products belong to women.

\section{Econometric Analysis}

Under this section, definition of the dependent variable and explanatory variables is briefly discussed in chapter three. Subsequently, the hypothesized explanatory variables are analyzed with the help of CD production function and the results interpreted. Therefore, fertilizer uses are higher than educational status.

The size of farmland holding at the disposal of a farmer is one of the most important variables affecting the level of farmers' gross value of farm output per ha. It has a significant and positive impact on productivity of agriculture in both $\mathrm{MHH}$ and $\mathrm{FHH}$, implying that the larger the land size, the higher is the yield. Other factors being constant, a $10 \%$ increase in the area under the major crops increases gross value of farm output by $3.83 \%$ and $3.06 \%$ for male and female headed households, respectively.

Accordingly, a study conducted in Ethiopia by Crop, Mulat (2009), assuming other factors remaining constant, more of the variation in productivity would come from the change in the size of cultivated land. This fact was also supported by the findings of Addis et al. (2010).

In this study, the variable that stands for male labor had a significant and positive impact on the gross value of farm output of MHH. A $10 \%$ increase in the amount of male labor resulted in $3.52 \%$ increase in gross value of farm output in $\mathrm{MHH}$, keeping other factors constant. This clearly shows that an increment of male labor use increases the output significantly. Moreover, a 10\% increase in female labor of the FHH increases output by $3.38 \%$, keeping others factors constant.

Herbicides had positive and significant impact on the productivity of the $\mathrm{MHH}$ and $\mathrm{FHH}$. A $10 \%$ increase in herbicides use resulted in $1.56 \%$ increase in output in both $\mathrm{MHH}$ and $\mathrm{FHH}$. This shows that an increment in herbicides use increases the output.

F-value for the overall difference in parameters is significant at 5\% level of probability, implying that there is a shift in production function between the two groups ( $\mathrm{F}$ tabulated=1.93).

Table: Estimates of Production Function for Sample with Dummy Gender

\begin{tabular}{lcc}
\hline Explanatory Variables & Regression coefficients & t-value \\
\hline Intercept & 4.660 & 21.018 \\
Livestock holding & 0.136 & 1.845 \\
Land size & 0.344 & 4.422 \\
Education level & 0.062 & 0.995 \\
Fertilizer use & 0.039 & 0.508 \\
Herbicides use & 0.153 & 2.543 \\
Male Labour & 0.184 & 2.457 \\
Female Labour & 0.265 & 4.053 \\
Dummy Gender (1 for & & \\
MHH, O=Otherwise) & -0.048 & -0.667 \\
Adjusted R & $57 \%$ & \\
F-value & 24 & \\
Number of observation & 140 & \\
\hline
\end{tabular}

Source: Own computation, 2019, NB: Significant at 5\% 


\section{Conclusion}

The main objectives of thesis are examined the impact of gender differences on crop productivity. The data used in this study were collected from $75 \mathrm{MHH}$ and $65 \mathrm{FHH}$ randomly selected from 6 PAs of the woreda. CD production function was estimated to measure productivity difference between $\mathrm{MHH}$ and $\mathrm{FHH}$.

The result also shows that MHH used more fertilizer, herbicides and credit compared to the FHH. In general, women farmers are disadvantaged in access to and control over resources compared to men farmers. Differences in access and control over resources between men and women seem to be a direct reflection of culturally prescribed gender division of labor. Legal, social and institutional factors can also create barriers for women farmers to have access to productive resources.

Women, in the study area, work for considerably longer hours than men. Clearly, there is limit to the time and energy that woman farmers can apply. Women's burden hinders their participation in education, training and/or extension activities. With regard to gender role, women play a significant role in agricultural production. They participate in all activities except ploughing using oxen, sowing and enset planting. This shows that agricultural activities are gender oriented in a certain manner.

Generally, findings of this study are provided relevant policy implications interventions that enhance household wealth index by reducing poverty would help enhance crop outcomes, reducing Gender gap among Woreda by launching appropriate strategy for Agricultural sectors, increasing crop productivity opportunities especially in rural areas by addressing fertilizer, seed, herbicide, land access and reduce the distance to market would help better crop outcomes.

\section{Recommendation}

Based on the findings of the study, the following points need to be considered as possible policy implications in order to increase the productivity of farmers in general and that of women farmers in particular.

Firstly, raising the productivity of land is central importance for increasing agricultural productivity through use of yield increasing inputs such as herbicides, and fertilizer.

Secondly, since livestock holding was one of the significant factors influencing agricultural productivity, intervention to improve livestock sector should be encouraged through empowering farmers to own livestock through provision of livestock credit. Furthermore, development of improved livestock feed should be encouraged by concerning bodies.

Thirdly, Women work greatly longer hours than men in the area. Most of their work such as enset processing requires more energy and consumes time. Thus, technologies that can reduce the time and energy of women in carrying out these activities should be developed and disseminated to women. Further researchers should be conducted on labor saving production technologies.

In generally, agricultural office should take appropriate measures to ensure its organizational mandates, objectives and commit to benefit women from its services by providing training, advisory services and continuous follow-up to assist women's crop production. Linkages with other governmental organizations like women and children offices and microfinance institution should be made to work cooperatively and address problems.

\section{REFERENCES}

Addis Tiruneh (2010). The Missing Link Between Micro and Macro Level Gender Disaggregated Economic Data in Economic Policy Formulation and Planning in Ethiopia. WID/ Department of Economics, Unpublished Paper, Addis Ababa University, Ethiopia.

Antle J. and Capalbo S.(2008). Agricultural Productivity Measurement and Explanation: Resource for the Future. Washington D.C, USA.

Bindlish V. and Evenson R.(2013). Evaluation of the Performance of T\&V Extension ,in Kenya, World Bank Technical Paper 208, Africa Technical Department Series, Washington D.C.

Boserup D.(2009). Women's Role in Economic Development, Routledge, London.

Buvinic M. and Gupta G.(2012).Women-headed Households and Women-maintained Families: Are They Worth Targeting to Reduce Poverty in Developing Countries? Economic Development and Cultural Change.

CISP (International Committee for the Development of Peoples) (1997). The Female Farmers Fertile Ground, A Gender Assessment Study of Agricultural Inputs Adoption in Rural Ethiopia, Ethiopia.

Coelli T.(2015). An Introduction to Efficiency and Productivity Analysis, Kluwer Academic Publisher, USA.

CSA (Central Statistics Authority)(2011). Statistical Report Vol.1, the 1994 Population and Housing Census of Ethiopia at Country Level, Ethiopia.

(2012).Ethiopian Child Labour Survey, Statistical Bulletin, Vol.262, Ethiopia.

Dejene Aredo. (2014). The Gender Division of Labour in Ethiopian Agriculture, A Study of Time Allocation among People in Private and Cooperative Farms in Two Villages, Ethiopia.

Elabour I.(2011).The Impact of Structural Adjustment Program on Women and Their Households, in Bendel 
and Ogun States, Nigeria: In Structural Adjustment and African Women Farmers, pp. 128-150, Gladwin, C.H (eds), USA.

Ellen K.(2013). Food Security and Child Nutrition: The Interaction of Income and Gender of Household, World Development, Vol.20, No 8-12.

Gujarat D. 1995. Basic Econometrics, 3rd ed. Mc Graw Hill Inc, New York.

Haymanot E.(2014). The impact of gender difference on crop productivity: A case study in Amhara Credit and Saving Institution. Unpublished level Thesis, Addis Ababa University, Ethiopia.

Heady E. and Dillon J.(2011). Agricultural Production Functions: Iowa State University Press, USA.

John B. and David D. (2011). Women and Development in the third world, New York.

Laura K.(2011). The Sociology of Gender :St. Martin's Press, New York, USA

Lisa G.and Ritu S.(2005). Women's Local Global Forum, Journal of the Society for International Development, No. $1-4$, p. 37.

MoFED (Ministry of Finance and Economic Development)(2015). Sustainable Development and Poverty Reduction Strategy Paper, Unpublished Paper, Ethiopia.

Moock P.(2011). Managerial Ability in Small Farm Production: An Analysis of Maize Yields in the Vigha Division of Kenya, PhD Dissertation, Columbia University, New York.

Solow R.(1957). Technical Change and Aggregate Production Function: Review of Economics and Statistics 24 , pp.312-320.

Tiruwork Tizazu (2010). Access to Resources and Productivity of Female-headed Households: The Case of East Gojjam and North Shoa, MA Thesis, Addis Ababa University, Ethiopia.

World Bank(2015a). The World Bank Partnerships for Development, Published by Creative Communicates Group for the World Band, USA. 